\title{
Universal, acid: Houellebecq's clones and the evolution of humanity
}

\section{Niall Sreenan}

To cite this article: Niall Sreenan (2018): Universal, acid: Houellebecq's clones and the evolution of humanity, Modern \& Contemporary France, DOI: 10.1080/09639489.2018.1557130

To link to this article: https://doi.org/10.1080/09639489.2018.1557130

曲 Published online: 21 Dec 2018.

Submit your article to this journal $[\pi$

Џlll Article views: 7

View Crossmark data ¿ 


\title{
Universal, acid: Houellebecq's clones and the evolution of humanity
}

\author{
Niall Sreenan \\ Centre for Modern Literature and Culture, King's College London, UK
}

\begin{abstract}
This article examines Houellebecq's two genomics novels, Les Particules élémentaires and La Possibilité d'une île and elaborates their relationship with Neo-Darwinian evolutionary naturalism and neoliberal capitalism. In these works, the mutual interdependence of these two regimes of thought both necessitates and makes possible the technology of human cloning, which promises humanity an escape from the misery of its own biological, political predicament. Houellebecq's work, I show, problematises this dialectic, and in doing so offers an incisive critique of utopian posthumanism, providing instead only an aporetic-but rigorously materialist-form of hope.
\end{abstract}

\section{RÉSUMÉ}

Cet article examine les deux romans génomiques de Houellebecq, Les Particules élémentaires et La possibilité d'une île, et développe leur rapport avec le naturalisme évolutionniste néo-darwinien et le néolibéralisme. Dans ces romans, l'interdépendance mutuelle de ces deux régimes de pensée nécessite et rend possible la technologie du clonage humain, qui promet à l'humanité d'échapper à la misère de sa propre situation politique et biologique. Je montre que l'œuvre d'Houellebecq problématise cette dialectique et, ce faisant, offre une critique tranchant du posthumanisme utopique, ne fournissant au contraire qu'une forme d'espoir aporétiquemais rigoureusement matérialiste.

Dès lors qu'une mutation métaphysique s'est produite, elle se développe sans rencontrer de résistance jusqu'à ses conséquences ultimes. Elle balaie sans même y prêter attention les systèmes économiques et politiques, les jugements esthétiques, les hiérarchies sociales. Aucune force humaine ne peut interrompre sons cours-aucune autre force que l'apparition d'une nouvelle mutation métaphysique.'

—Michel Houellebecq, Les Particules élémentaires $(1998,10)$

Someone once said that it is easier to imagine the end of the world than to imagine the end of capitalism. We can now revise that and witness the attempt to imagine capitalism by way of imagining the end of the world. 
How can replicating the human create a new species? How does repetition liberate humanity from a biological and social system-a metaphysics-that reproduces and determines its subjects in the same movement? Houellebecq's two genomics novels, Les Particules élémentaires (1998) and La Possibilité d'une île (2005a), seem to offer us an answer to these questions. In these works, genomic cloning promises humanity freedom from the violent and deterministic reproductive relations of late capitalist society as well as evolutionary biology: the clone is an autonomous, biosocial territory, withdrawn from the myriad cruelties of Neo-Darwinian neoliberalism-constituting, de facto, a new species of emancipated human. This essay seeks to scrutinise this fictional solution and to illuminate its relation to current political and biological discourses in contemporary Western society. Does Houellebecq's genomic proposition for liberation offer a hopeful critique of and solution to the crisis in contemporary capitalism? Or, does such desire for transcendent withdrawal amount to nothing other than pathetic renunciation, and biological nihilism?

The preface to Particules frames the process of liberation through biological cloning within a tripartite scheme of socio-historical development. This is explicitly grounded in August Comte's theory of social evolution, according to which humanity proceeds through three stages of development: theological, metaphysical, and positive. One of the novel's two protagonists, the gifted, depressive bio-physicist, Michel Djerzinski, is the founder of a new paradigm in genetic theory, from which is developed a genomic technology for frictionless and efficient human reproduction and the obsolescence of sexual relation and desire. This discovery, disclosed in full in the novel's epilogue, at the conclusion of Djerzinski's tortured life, is understood as ushering in the final or 'positive' stage in the development of society. This is what the novel's narrator calls the third and most radical 'mutation métaphysique' in human history: 'les transformations radicales et globales de la vision du monde adoptée par le plus grand nombre' ['a radical, global transformation in the values to which the majority [of people] subscribe'] (Houellebecq 1998, 9, 2001, 4). Humanity is released from its previous sociohistorical constraints-'materialism', the metaphysical stage (itself the successor to the theological stage of Christianity), which is characterised by the pervasion of biological determinism, the agony of sexual longing, the affective desert of consumer capitalism, social anxiety, and the empty surrender brought about by the foreknowledge of death. Through the infinite self-repetition of genetic cloning, humanity in the twenty-first century transcends this, reaching ecstatic being via an immortal state of total biological, social, and existential stasis.

Houellebecq's later novel, Possibilité, can be read as a companion to Particules-or perhaps its clone. Partly narrated from the perspective of two 'neohuman' replicants, Daniel24, and later Daniel25, it explores in further detail the positive stage of which the earlier novel offers a sketch. The neohumans in this novel transcend the agonies of the materialist world, devoid of desire, sexual or otherwise; each clone lives in an individual, self-sustaining walled compound, drawing nutrition autotrophically from minerals present in the atmosphere, reproducing itself through a centralised industrial cloning system that delivers a new neohuman iteration immediately upon the death of its predecessor. In the earlier work, the materialist stage is framed by a prefatory theoretical description of the positive stage and its epilogic narrative realisation. The later novel's structure oscillates between the autobiographical narratives of Daniel24 and Daniel25 and their originary predecessor from the twenty-first century, Daniel1. In the earlier work, neohuman existence is characterised by infinite 
and uninterrupted tranquillity. Daniel1, a caustic satirical comedian, who like Djerzinski is one of the key instigators in the metaphysical mutation towards neohumanity, is also throughout his life marked by self-lacerating depression, unfulfilled sexual hunger, and existential pain.

Each novel, then, juxtaposes two distinct stages of human evolution and in its formal rhetoric dramatises the shift from one to the next: the despair of the metaphysical or materialist stage in the late-twentieth and early twenty-first centuries to the comparative bliss of a neohuman future. In both novels, metaphysical liberation of humanity from materialism-or the transition from the metaphysical to the final positive stage-is catalysed not by evolutionary change, but by recurrence, the intensification of the conditions of the materialist stage and, specifically, the possibility of biological repetition through techno-scientific progress in evolutionary genetics. As Djerzinski's colleague, Walcott, observes, materialism does not necessarily develop a higher form of human existence, but is in fact 'incompatible avec l'humanisme, et devait finir par le détruire' ['antithetical to humanism and would eventually destroy it']. Although he does not live to see his prediction called into question by the development through materialist conditions of a neohuman state of transcendence, Walcott's cynicism will prove to be well-founded. For the final stage of this process of evolution is not a higher form of existence founded on humanist principles, but the logical conclusion of all evolution: the replacement of humanity through the creation of a new, post-human species (1998, 373, 2001, 359).

I wish to analyse how Houellebecq's cloning stories dramatise this dialectic, revealing in the 'materialist' stage of life an insidious coalition between capitalist hegemony and evolutionary science. Specifically, I shall be examining how in these two works human relations are permeated by a vulgar Darwinism, wherein brutal competition for survival, heedless individualism, and biological determinism pervade human life. This is matched, indeed intensified, in these novels by the advent of what Fredric Jameson calls 'late capitalism', a globally pervasive, state-enforced, mediatised, self-reproducing cultural logic of free-market competition, automation, and individualism-as well as the extension of that logic into all forms of human relation, whether affective, interpersonal, or libidinal, as well as economic and political (Jameson, 1991, vii-xxii). Houellebecq's clones, I shall be arguing, are a bio-technological response to what Houellebecq calls the materialist 'market society', where 'the entirety of human relations [...] are mediated via a simple numerical calculation entailing attractiveness, novelty, and value for money' - the product of what Carole Sweeney in her analysis of Houellebecq's work calls the 'encroachment of capitalism in its neoliberal biopolitical form' (Harraway 1991, 43; Sweeney 2013, ix). The relation of Houellebecq's work to what might be called late capitalism, neoliberalism, capitalist governmentality, or the subjectification of the homo economicus has been well documented and acutely analysed (Best and Crowley 2007; Crowley 2012; Sweeney 2013). Likewise, numerous critics have identified and explored Houellebecq's preoccupation with biological discourses and scientific reductionism (McCann 2010; Morrey 2013; Rabosseau 2010; Woollenn 2013). In what follows, therefore, I seek to develop an account of how in the figure of the human clone these two streams of thought are knotted in Houellebecq's two novels. In doing so, I aim to demonstrate Houellebecq's complexity as an interlocutor in contemporary debates around genomics and posthuman futurity. 
Houellebecq's clones critique biological nihilism and political despair but also problematise naïve optimism. As such, these works provide us with a more ambivalent and rigorous conception of social and biological materialism than the schematic quasiComtean account of human evolution discussed earlier.

\section{Neo-Darwinism; neo-naturalism}

In a recent critique of contemporary sociobiology and genomics, Hilary and Steven Rose note how widespread is the language and logic of genetic and evolutionary determinism (Rose \& Rose, 2012). Everywhere one cares to look, they argue, 'metaphors of DNA, hard-wiring, Darwinian natural selection and evolution [are] invoked by the media or politicians' $(2012,277)$. Furthermore, symptomatic of Darwinism's and genetics' discursive universality, a 'deference to the determining authority of the life sciences' has crept into humanist disciplines-which, if not antithetical to evolutionary accounts of the human condition, usually seek to avoid the empiricism and reduction necessary to natural sciences (278). '[P]hilosophy, art, ethics, sociology, politics, and law' are expected at the very least to articulate their relation, whether positive or negative, to evolutionary biology and its implicitly essentialist epistemology (278). Often, that relation is one of uncritical acceptance; genes are claimed to be responsible for, among other things, male violence, female coyness, voting intentions, the nature of art, and, tellingly, the 'inevitability of a neoliberal economy' (22).

The formal imperialism of this Darwinian thinking extends to its conceptual content, which affirms the supremacy of evolutionary utility, profit, and competition over all human existence and agency. Unlike Comte's notion of human development, Darwin's theory of 'the struggle to survive' is non-teleological, driven not by an additive dynamic of emancipatory progress, but by elimination. For the biologist and theorist Stanley Shostak, this means biological science has a decisively simple, but brutal, conceptual lodestone: 'Natural selection is ordinarily supposed to power evolution by sifting variations in life's forms through an environment filter. The filtrate evolves; the sediment expires' (Shostak 1999, 231). Daniel Dennett takes this further, asserting the transcendence of this law, conceiving of natural selection as a 'universal acid'; an idea 'capable of cutting right to the heart of everything in sight', whose logic exceeds mere biological phenomena but encompasses 'the universe as a whole, from gas to genius' (Dennett 1996, 521; Midgley 2000, 73). In this way, evolutionary determinism becomes a cosmology. The human species has no historical purpose or direction, but is driven at the level of its fundamental biological being to struggle, a concept which itself remains untouched by the constant flux of actual living matter.

It is also in this way, to return to Rose and Rose's original thesis, that Neo-Darwinian evolutionary thinking nourishes and is, in turn, nourished by the hegemony of contemporary, or in their terms, neoliberal, capitalism. Although new forms of Darwinian thinking in psychology, economics, philosophy, and elsewhere are marked by their incorporation of techno-scientific advances in genomics and neurology, the touchstone for Neo-Darwinian explanations of the complexity of human life is an almost Hobbesian notion of bellum omnes contra omnium. The 'evolutionary synthesis' of Darwinism and genetics can be dated to the 1960s, as an answer to the empirical and conceptual lacunae in traditional Darwinian evolution, which could not yet fully account for the 
reproduction of certain biological traits (Bowler 1989, 312-314). Trace further back, however, and it becomes clear that Neo-Darwinism is less a new synthesis, but a continuation of the close conceptual reliance of evolutionary Darwinism on freemarket capitalism. As Darwin concedes in the Origin of Species, natural selection's conception of constant competition for survival owes a debt of influence to the 'doctrine of Malthus', setting resource scarcity against population growth and predicting constant struggle (Darwin 1859, 5). Marx's initial enthusiasm for Darwin's biological-historical materialism is replaced by ideological suspicion: 'It is remarkable how Darwin recognises among beasts and plants his English society with its division of labour, competition, opening-up of new markets, "inventions"' $(1965,128)$. Later in the century, Herbert Spencer's coining of the phrase 'the survival of the fittest' provided evolutionist capitalist thinkers and Spencer himself with post facto biological authorisation for the notion of a divine and efficient market (which ironically, as Marx points out, was already dominant in English society) (Hawkins 1997, 89-90).

Today, the kinship between what Shostak critically designates 'ordinary' or institutional biology's account of evolution and the ideology of free-market competition is not disavowed but explicit. Richard Dawkins has made famous the theory of the 'selfish gene', the notion that we are mere fleshly vessels determined by an infrahuman struggle to survive (Dawkins 1989). The biologist E.O. Wilson argues that the heterogeneous gene pool of pre-modern civilisation was a 'free market of genetic diversity', suggesting that whatever human genetic 'market' exists today does so as a set of competitive circumstances beyond our control (Wilson 1998, 299). Similarly, 'free trade, the rule of law, and sound market practices' provide stability in contemporary society; while further 'government subsidy in the free-market economy' can solve the Malthusian problem of population growth (Wilson, 316-318). Wilson posits that the answer to the inherent problems of biological struggle is the enforcement of economic competition-eroding the difference between the two, while at the same time raising the possibility that what Michel Foucault calls in his lectures on biopolitics 'pure competition' is not natural but a historically specific form of governance (Foucault and Senellart 2008, 120-121). Either way, as a spontaneously arising phenomenon as well as a mode of economic organisation that requires enforcement, the struggle to survive is understood here as biopolitical rationality.

Houellebecq's work, as several critics have argued, describes a world almost entirely determined by such logic. Houellebecq's fiction, John McCann says, 'takes place in a Darwinian world', where, echoing Marx's reading of Darwin, human progress is not characterised by melioration, but by the centrality of a struggle which 'eliminates those who do not fit into the circumstances' (McCann 2010, 8). In Possibilité, this dynamic reaches a grotesque conclusion: during a particularly severe (probably anthropogenic) heat wave in France, thousands of elderly people-deemed valueless-die in conditions similar to concentration camps as a result of wilful neglect. For Douglas Morrey, such a collapse in care for others is partly a function of the extension of capitalist rationality to libidinal or affective relations; Daniel1 experiences the process of ageing as a gradual decrease in sexual value and, thus in his value overall. For Morrey, however, this originates also in the notion of a 'deep atavistic heritage that serves to underline these aspects of human behaviour as so many evolutionary facts' (Morrey 2013, 131). Geoff Woollen points out that for English readers Houellebecq's evident concern with 
evolution and Darwinism is masked by the translation of Extension du domaine de la lutte (literally, The Extension of the Area of Struggle) as Whatever (Woollenn 2013); but the ambivalence of the term 'lutte' and its translation illustrates that 'struggle' for Houellebecq is neither entirely biological or sociopolitical, but determined by the two together. Houellebecq, these critics show, grants evolutionary thought the significance of having ethical and social implications. Underlying this is a sense of the pervasion of the brutality of evolutionary Darwinism in contemporary life-both at the level of discourse, which in Woollen's example is disavowed by the act of translation, as well as at the level of daily economic, social, and sexual experience.

Both Woollen and Sandrine Rabosseau note the similarity of Houellebecq's use of biological naturalism to that of Émile Zola. The latter gives this identification fuller critical treatment, arguing that Houellebecq is the proponent, in her terms, of a literary 'neo-naturalism' which functions to extend the socio-biological, hereditary preoccupations of the literary Naturalist tradition into the twenty-first century, simultaneously offering a postmodern pastiche of the Zolian novel (Rabosseau, 106). This comparison with Zola is instructive. David Baguley has shown that Zola was not a detailed reader of Darwin, drawing his scientific sources instead from French evolutionists, sociologists, and physiologists (Baguley 2011, 2014). Zola, however, does respond in novels such as Germinal and La Debâcle-to a popular abstraction of Darwinism found in bowdlerisations, translations, and tendentious interpretations of Darwin. In other words, Zola does not essay an 'experimental novel' informed by Darwinian science, but responds instead to what Paul Lafargue called 'the drawbacks of [Darwin's] popularity'; to the implications of Darwinism entering popular discourse and consciousness as a scientific theory of social and political struggle (Lafargue 1890).

Zola indicated in his Ébauches that La Debâcle sought to call forth the grand idea of Darwinian evolution dominating the comparatively insignificant human individual (Baguley 2014, 419). At the same time, the novel satirises the mode of transmission by which such a theory could become simplified and dangerously political: young enthusiasts of the Franco-Prussian war derive their faith in conflict from fashionable but nakedly ideological accounts of evolution (Zola, 1892, 28). Similarly, the protagonist of Germinal encourages a disastrous general strike, causing widespread death and destruction, based on a Darwinian conception of Marxist historical determinism picked up from cheap, ten-sous pamphlets (Zola 1978; Sreenan 2014). Houellebecq's treatment of Darwin is analogous to that of Zola. He is not evidently a sophisticated interpreter of the nuances of Darwinian theory, but insightful in exactly the opposite way. Martin Crowley has argued that Houellebecq offers us a minimal kind of critical 'derisory lucidity' in his work being itself a degraded conduit of a degraded time. Houellebecq's 'Darwinian universe', his dramatisation of biological struggle and, as I shall show, his adoption of a Neo-Darwinian vernacular enacts and satirises the debased Darwinian cosmology of our time (Crowley 2012, 149). The Darwinian theorists I have mentioned, Dennett, Dawkins, Wilson, are popularisers as much as Darwinian biologists, and Houellebecq's Neo-Naturalism responds to this vulgar or popular conception of Darwin, just as Zola did, with vulgarity. The question remains as to whether this insight or lucidity offers more than Zola's implicitly critical commentary, or even 'a small cry of protest', against a biopolitical rationality that has transcended popularity and become immanent to the textures of human relation. 


\section{Houellebecq's bio-capitalist realism}

It is via the hegemonic victory of capitalism in the twentieth and twenty-first centuries that Darwin's 'dangerous idea' comes to transcend its broad popularity in the nineteenth century, to dominate humanistic discourses (Rose \& Rose) and then, as I suggest, to become immanent to social, sexual, affective, and political relations. For Jason Moore, humanity has since the fifteenth century been living in the 'Capitalocene', a geohistorical period in which nature itself-climate, ecology, physical geography-is reorganised around humanity's endless pursuit of profit (Moore 2015, 172-173). Following Marx, therefore, the advent of Darwinian natural selection in the mid-nineteenth century supports in biological terms the ideology of free market competition, but also the idea that this ideology is inscribed at the foundational levels of our material, biological existence as humans. This redoubles the sense of Darwinism's pervasion in political social reality, an ecological version of what Mark Fisher, adapting Jameson's work on postmodernity and the logic of late capitalism, calls Capitalist Realism (Fisher 2009). Life under neoliberalism, Fisher writes, is poisoned by the 'widespread sense that not only is capitalism the only viable political and economic system, but also that it is now impossible even to imagine-let alone construct-a coherent alternative to it (2009, 2). Popular culture especially, Fisher demonstrates, has renounced imagining the new and is content instead to live within the comfort of a boundless present, and to offer entertainment through a combination of apocalyptic fantasy and nostalgia. Such a diagnosis, as we shall see, is crucial to understanding Houellebecq's pre-occupation with evolution.

For David Harvey, neoliberalism enforces such superstructural nihilism with deliberate economic policy: the state provides a guarantee of so called competitive 'free markets' through the privatisation of public wealth, the creation of markets in public services, and minimising state intervention $(2005,2)$. The paradoxical enforcement of market freedom, Wendy Brown argues, epitomises the neoliberal mobilisation of law not to repress or punish, but to structure competition and effect 'the conduct of conduct' $(2015,148)$. Neoliberalism, Brown asserts, has transcended economic logic and ideology to become an entire 'political rationality', through which the horizons of human imagination and representation-and therefore the horizons of human agency-are bound by a set of explicit and implicit regulations hostile to alternative ways of conceiving human relations. Neo-Darwinian and genomic discourse tighten neoliberal capitalism's stranglehold on the imaginative, political, existential limits of human society. It is not only the case that evolutionary biology and genomics are dependent on profit as institutionally viable practices. These discourses claim an exhaustive vision of reality, through which they reinforce the sense of capitalism's total capture of human life that Fisher, Harvey, and Brown seek to analyse in cultural, economic, and political contexts. Fisher's work may be the least rigorous of these three thinkers, but it does furnish us with the most useful phrase. Capitalist realism in its Neo-Darwinian guise creates the conditions within which it is not merely impossible to imagine a world outside capitalism but beyond the capacity of our biological evolution. This even goes beyond Moore's geological concept, since his diagnosis in its substitution of 'capital' for human in the term 'Anthropocene' differentiates humanity from capitalism as such, suggesting the possibility of the former moving beyond the latter. Capitalist realism nourishes the claim that such utopian 
thought is contrary to fundamental biological and genetic possibility. Capitalist reality and evolutionary biological reality become mutually reassuring metonyms-describing the same restlessly shifting but fundamentally invariable world.

Houellebecq's Particules and Possibilité are generically science fictional, but respond to the current neoliberal biopolitical juncture with a literary rendering of 'capitalist realism' which I have previously called, after Rabosseau, Neo-Naturalism. The earlier work offers a cultural history of the advent of neoliberalism in Europe and France, embodied in the 'Lieu de Changement', a fictional proxy for the 'L'espace du possible' holiday settlement in Meschers-sur-Gironde. Founded by a group of soixante-huitards in the mid-seventies, the original purpose of Houellebecq's 'Lieu de Changement' was to offer people the opportunity to enact utopian ideals in the 'ici et maintenant' as opposed to the 'nowhere' implicit in utopian theory $(1998,122)$. To that end, the Lieu was created as a zone of autonomy from everyday life, within which like-minded people could live in the Summer months joyfully practicing democratic principles and, in its founders' terms, 'baiser un bon coup' ['get your rocks off'] (Houellebecq 1998, 98, 2001, 114). By the 1980s, this spatio-temporally partial and fundamentally hedonistic utopia finds itself incorporated by the very capitalist hegemony from which it sought to withdraw. In order to counteract financial losses caused by its aging clientele and facilities, as well as cultural aversion to the outdated anarchism upon which it was founded, a typically neoliberal solution is put forth: 'Une brève lutte de pouvoir interne eut lieu, et l'association loi 1901 qui gérait l'endroit fut dissolute pour être remplacée par une SARL' ['After a brief internal power struggle, the Lieu ceased to be an association under the act of 1901 and became a publicly traded corporation'] (1998, 127, 2001, 120). A number of years later, the Lieu was offering residential courses to businesses in Zen meditation, communication, Gestalt therapy, and other skills, and had an estimable list of corporate clients: 'BNP, IBM, ministère du Budget, RATP, Bouygues...' (128; 120). By the time Djerzinski's sexually monomaniacal half-brother, Bruno, visits, the Lieu has entirely transformed. It has become a kind of New Age, bourgeois flesh market where sex is a commodity competed for by its visitors. It has also become an explicitly capitalist venture, whose former utopian beginnings are present only as traces-a Bakuninian slogan on the camp gates, signs exhorting mutual respect-and are maintained principally for the purposes of monetisable nostalgia.

Here, capital destroys its opposition not through force but by the paradoxical imposition of further freedom: it co-opts the ideals and aesthetic of revolution and sells them back to a society it has already rendered incapable of imagining meaningful forms of political resistance. The visitors to the Lieu exist in a state of pure present, in perpetual competition for sexual gratification, relishing the camp's nostalgic atmosphere. They no longer function, even temporarily, outside the grasp of capital, but have interiorised its fundamental principles. This process of political submission echoes Fisher's and Brown's analyses of neoliberal influence, and traces the historical arc of Harvey's account of neoliberalism in the West: a process beginning in the 70s in response to rising inflation, made possible by financial deregulation at the start of that decade, and becoming sealed in the 1980s with the ascendance of Ronald Reagan and Margaret Thatcher (Harvey 2005, 9). This development seems even to envelop parliamentary forms of socialist resistance as well as cultural modes of micropolitical action. 'Les années Mitterrand' were marked by the sudden retrenchment in 
1983 of austerity-based economic policy in response to global inflation (Lordon 2001). They were also a time, in Houellebecq's fictional France, when Djerzinski and his peers in genetic science benefited from the neoliberalisation of genomics, with venture capital supporting the foundation of companies designed to exploit commercially the potential if its new discoveries. Neo-evolutionary science, therefore, benefits from the privatisation of scientific funding, while this mode of political-economic organisation is ratified as natural and timeless in the epistemology and conceptual content of the new biology.

Houellebecq makes explicit the implications of this entanglement of capital and evolutionary biology for conceptions of human nature. The sexual economy of the Lieu, as well as its consumerist ideological substrate, is understood by its chief executive to have its roots in the atavistic, biologically rooted drives of human nature. At the same time, while the 'sexual revolution' of the 1960s embodied by the Lieu appears to efface traditional forms of courtship, this same chief executive asserts the fundamentally bourgeois concept of les soirées dansantes as the inevitable mode of sexual selection. Such conservative ritual, he argues, is a fundamentally unchanging trait of all human societies which, in primitive times, used feasts and dances to seek collective ecstasy. Vague notions of biologically determined 'human nature', therefore, are deployed not only to justify the free market model of political economy, but to extend that model to sexual and social reproduction.

The role that capital plays in naturalising its exploitation of desire is made explicit in Possibilité in a conversation between Daniel1 and his first wife, Isabelle, a teen-magazine editor. The latter argues that sexual success in the marketplace of flesh originates in an instinctual will to power, while economic success rests upon its acknowledgement and exploitation.

\footnotetext{
Si les filles sont attirées sexuellement par les types qui montent sur scène, poursuivit-elle, ce n'est pas uniquement qu'elles recherchent la célébrité; c'est aussi qu'elles sentent qu'un individu qui monte sur scène risque sa peau, parce que le public est un gros animal dangereux, et qu'il peut à tout instant anéantir sa créature, la chasser, l'obliger à s'enfuir sous la honte et les quolibets. La récompense qu'elles peuvent offrir au type qui risque sa peau en montant sur scène, c'est leur corps; c'est exactement la même chose qu'avec un gladiateur, ou un torero. II serait stupide de s'imaginer que ces mécanismes primitifs ont disparu: je les connais, je les utilise, je gagne ma vie avec. (Houellebecq 2005a, 34)
}

[If girls are sexually attracted to guys who get up on stage [...] it's not simply that they are seeking fame; it's also that they feel an individual who gets up on stage risks his neck, because the public is a big dangerous animal that can annihilate its creation, hunt it down, and force it to flee, booed off in shame. The reward these girls can offer to the guy who risks his neck by going on stage is their body; it's exactly the same thing with a gladiator, or a matador. It would be stupid to imagine that these primitive mechanisms have disappeared; I know them, I use them, I earn my living from them.] (Houellebecq 2005b, 25)

Just as the chief executive of the Lieu draws on the scientific authority of evolutionary thought for his assertion that bourgeois forms of sexual courtship and competition are rooted in essential human nature, and in turn to exploit that, Isabelle does the same with an essentialist narrative of atavistic female sexual desire for male power. Their conceptions of human sexual desire are obviously reductive; but they are also, despite their scientific pretension, ahistorical and anti-materialist, positing desire as immune to economic and social situation and their interface with gendered power relations. And 
yet, the success of their respective businesses confirms empirically for them the scientific realism of their theses, just as their misanthropic notions of human nature authorise an amoral, pragmatically realist approach to economic exploitation. Houellebecq's staging and critical illumination of the neoliberal logic of the re-invented Lieu and teenage magazines rests on the mutual reinforcement of the respective realisms of capitalism and neo-evolutionary biological essentialism.

\section{Surviving the struggle to survive}

Houellebecq's works are not content with diagnosing the epistemological enmeshing of neoliberal capitalism and evolutionary essentialism. Rather, they clarify its ramifications and articulate how it is experienced, often in the form of emblematic popular culture ephemera and artworks; sometimes-as in the case of the Lieu-drawn from real-life examples; at others invented by Houellebecq himself. One striking iteration of the latter is one of Daniel1's violent, satirical television programmes that stages an encounter between a Palestinian 'terroriste du Hamas' and a German tourist on the question of the value of human life, as they brutally torture a hostage (2005a, 48). As the Hamas member commits a series of pitiless acts of violence on his hostage, another terrorist intervenes and a brief discussion ensues in vaguely Darwinian terms. As they castrate him, the two terrorists conclude that, from a purely Darwinian perspective, the biological value of the hostage had changed, while his economic value remained high. On the one hand, we can read this parable as a darkly comic critique of the conflation in neoliberalism of economic and biological notions of value. On the other hand, the notion of a biological struggle is transposed into a political one-between Hamas and its opponents - and thereby constructed as a natural, evolutionary existential battle rather than a historically contingent political war. The overriding effect of this exchange, however, is that of repulsion. Houellebecq employs the violent aesthetic of literary Naturalism to delineate in painstaking detail the effects of this warfare: the terrorist first tears out the hostage's teeth, proceeds to do the same to his fingernails, and completes the torture by rending the hostage's testicles. Although it is couched in biological, Darwinian logic, the partly disavowed political economic context of this brutality is key. Limiting conceptions of human value to either a purely biological, economic, or biological-economic logic reduces human society to a kind of barbarous realism, from which our self-imposed epistemological constraints allow us no escape.

Particules offers a similar vision of endemic and inescapable social Darwinian savagery. The ur-narrative of Darwin's struggle to survive saturates the novel, first appearing in detail in the fictional-but recognisable-television programme, 'La Vie des animaux'. Bruno watches this as a child with a mixture of awe and trepidation:

Les gazelles et les daims, mammifères graciles, passaient leurs journées dans la terreur. Les lions et les panthères vivaient dans un abrutissement apathique traversé de brèves explosions de cruauté. Ils tuaient, déchiquetaient, ils dévoraient les animaux les plus faibles, vieillis ou malades; puis ils replongeaient dans un sommeil stupide, uniquement animé par les attaques de parasites qui les dévoraient de l'intérieur. (Houellebecq 1998, 47)

[Graceful animals like gazelles and antelopes spent their days in abject terror while lions and panthers lived out their lives in listless imbecility punctuated by explosive bursts of 
cruelty. They slaughtered weaker animals, dismembered and devoured the sick and the old before falling back into a brutish sleep where the only activity was that of the parasites feeding on them from within.] (Houellebecq 2001, 38)

Houellebecq's choice of television, here and in Possibilité, as the medium with which to stage simplistic but affecting parables of Darwinian cruelty is noteworthy. This rote description of La Vie des animaux can be read as an allegory for the pitiless, mechanically eliminative milieu within which Houellebecq's novels take place; while the cartoonishly violent torture scene above is a metaphor for a society which conducts its wars on the basis of Darwinian and economic conceptions of human value. Confined to a psychiatric hospital in later life, Bruno writes a film script set in a utopian future in which La Vie des animaux exists only as testimony to 'de la barbarie des époques antérieures' ['the barbarity of previous eras'] (2005a, 322; 2001, 310). Like Zola's pamphlets, that these narratives are transmitted through a popular medium is important, since television-a totem for a fully mediatised neoliberal society-allows those narratives to assume an unquestioned and universal position of dominance in a wider ideological superstructure. The human animal lives in a society no different to that of the gazelle, or the lion, or the parasites that feed upon them; the question is whether you will be a predator or a victim.

If we read Lieu de Changement as a synecdoche for Western society at large, and the sexual economy within as a corollary of the hegemony of a crudely Darwinian, biologically essentialist Weltanschauung, Bruno's boarding school-another notionally autonomous space-can also be said to represent society (and, therefore, nature) in this way. Here, again, hierarchy, competition, and suffering are understood in facile biosocial terms:

Les sociétés animales fonctionnent pratiquement toutes sur un système de dominance lié à la force relative de leurs membres. Ce système se caractérise par une hiérarchie stricte: le mâle le plus fort du groupe est appelé animal alpha; celui-ci est suivi du second en force, animal bêta, et ainsi de suite jusqu'à l'animal le moins élevé dans la hiérarchie, appelé animal oméga. Les positions hiérarchiques sont généralement déterminées par des rituels de combat; les animaux de rang bas tentent d'améliorer leur statut en provoquant les animaux de rang plus élevé, sachant qu'en cas de victoire ils amélioreront leur position. Un rang élevé s'accompagne de certains privilèges: se nourrir en premier, copuler avec les femelles du groupe. Cependant, l'animal le plus faible est en général en mesure d'éviter le combat par l'adoption d'une posture de soumission (accroupissement, présentation de l'anus). (Houellebecq 1998, 98)

[For the most part, animal societies are structured according to a hierarchy in which rank relates directly to the physical strength of each member. The most dominant male in the group is known as the alpha male, his nearest rival the beta male, and so on down to the weakest of the group, the omega male. Combat rituals generally determine status within the group; weaker animals try to better their position by challenging those above them. A dominant position confers certain privileges: first to feed and to couple with females in the group. The weakest animal, however, can generally avoid combat by adopting such submissive postures as crouching or presenting the rump.] (Houellebecq 2001, 51)

The biologisation of the power relations between children in a boarding school not only mirrors Isabelle's thesis in Possibilité on the nature of female sexual desire, but also the power dynamic of the animal kingdom in Bruno's childhood television programme. In this 'primitive' milieu Bruno's position of weakness is anticipated and confirmed by the popular culture he consumes, and in accordance with the necessary power relations 
of natural selection he is violently abused, both physically and sexually. Houellebecq, of course, spares us no detail in describing the abuse: Bruno is beaten, urinated upon, sexually assaulted, and threatened with a razor blade to his genitals. His humiliation and suffering, it is implied, derives from his failure in a competitive Darwinian milieuinscribed and mutually reinforced at the levels of culture, society, and nature-from which there is no escape.

Competition, the struggle to survive, what Daniel1 designates the 'théses darwiniennes les plus élémentaires' ['the most elementary Darwinian arguments'], saturates human relation in these novels, its essentialist, instrumental, and violent logic interceding itself in economic, social, sexual, political, and economic modes of acting and understanding action (Houellebecq 2005a, 110). It is a literary synthesis of what Rose and Rose identify in their analysis of contemporary everyday discourse. The evolutionary story of the 'survival of the fittest' - mediated by an already crudely Darwinian neoliberal ideology-has become immanent to the very texture of contemporary life. Popular culture, television, magazines, the locus of shared narratives in late capitalism reflects this, as does Houellebecq's own obscene rendering of its effects, disallowing readers distance from either the pervasion of the logic of struggle or from our complicity in it as avid consumers of its cultural forms. This is a thoroughgoing, modified iteration of Fishers' capitalist realism. Whatever critical incision we might gain in relation to humanity's entrapment in an epistemologically reinforced biopolitical regime of barbarism, its potential is dulled by these novels' further clarification that we are ourselves complicit in its continuation.

\section{Evolving out of evolution}

Houellebecq's insistent thematisation of Darwin's 'universal acid' both stages and enacts the manner in which politics, economics, and desire have in the age of universal neoliberal rationality become saturated by the logic of biological warfare. But the subject and formal rhetoric of his clone novels suggest that the possibility of a qualitative break from this metaphysical condition lies precisely in the same materialism that condemns us to barbarism and suffering. In both novels the capitalist, Darwinian realist narrative perspective of the present is breached by narratives from another temporal and epistemic point of view: the post- or neohuman perspective of the clone.

In Particules, this is accomplished by the epilogue and prologue, from where and when it is understood the novel's narrator is derived. As well as offering us the narratives of Djerzinski and Bruno, this unnamed voice provides us with distance, a panoramic vision of the development of auto-reproductive genomic technology developed by a scientist named Hubczejak which Djerzinski's theoretical work has made possible. The narrator describes how, through a marketing campaign exploiting New Age rhetoric and the widespread desire to escape 'tortured, contradictory, individualistic, quarrelsome' materialism of the twenty-first century, popular political consent is established for the notion that humanity itself 'must disappear and give way to a new species which was asexual and immortal, a species which had outgrown individuality, separation and evolution.' (Houellebecq 2001, 379)

There are two paradoxes here: that humanity must harness the powers of evolutionary development and commerce to save itself from the barbarism of evolution and capitalism, and that doing so precipitates the end of the human as a species. The 
dialectical movement of the former, evolving beyond the constraints of evolution, is not limited merely to the possibilities of new forms of genetic development made possible by commercially driven scientific research. It is also widespread epistemological deference to capitalist and scientific realism which makes escaping this thinkable. Speaking of the New Age vanguard of neohumanity, the narrator observes:

Comme tous les autres membres de la société, ils pensaient au fond d'eux-mêmes que la solution à tout problème- $y$ compris aux problèmes psychologiques, sociologiques ou plus généralement humains—ne pouvait être qu'une solution d'ordre technique. (Houellebecq 1998, 385)

[Like others in society they truly believed only in science; science was to them the arbiter of unique, irrefutable truth. Like others in society, they believed in their hearts that the solution to every problem - whether psychological, sociological or more broadly humancould only be a technical solution.] (Houellebecq 2001, 377)

Thus, when Hubczejak successfully synthesises an auto-reproductive human immune to the agony of sexual desire, to the competitive impetus of both capitalism and evolution, and thereby to the existential pain of life, this techno-scientific solution is widely embraced. Fifty years later, the narrator observes, the old human species is in terminal decline and has largely been replaced by the neohuman era. 'The forces of egotism, cruelty and anger' that characterised the materialist era have been transcended and replaced by a new world order that is defined by pure serenity and joy. In other words, the Neo-Darwinian, neoliberal age of materialism is its own gravedigger, supplying its subjects with conceptual and technological means-as well as the urgent desire-with which to transcend it.

This is an optimistic reading of Particules, not unlike the enthusiastic technophilia proffered by contemporary advocates of transhumanism and genomic progress. Houellebecq's vision of a techno-scientifically driven post-human solution to the pedestrian agonies of the human condition is notably similar to Ray Kurzweil's notion of 'The Singularity' in which he projects continuous, exponential technological progress and the development of highly sophisticated 'information-based technologies', which will 'encompass all human knowledge and proficiency' (Kurzweil 2006, 8). This, Kurzweil argues, will enable humanity not only to exceed the 'myriad of failure modes' and 'cumbersome maintenance rituals' of biologicity, but also to reach a state of intellectual transcendence beyond the 'derivative, petty, and circumscribed' nature of normal human thought $(2006,8)$. The futurist, Nick Bostrom, proposes an analogous but politically inflected resolution. To reach a state of 'perpetual peace', Bostrom theorises the necessity of a 'singleton', a 'global regime that could enforce basic laws for its members', shaping the trajectory of human evolution through surveillance, taxation, and positive eugenics, to ensure the stability and flourishing of the human species and its civilisation (Bostrom 2004). Further knowledge of our genetic origins, E.O. Wilson argues, makes possible 'volitional evolution': altering the human genome in order to enter a third phase of human development. However, to the extent that Houellebecq does offer a solution to the problems of life under neoliberal materialism, it involves not the liberation of humanity, but the creation of distinct species, and humanity's elimination. This refuses the contradictory humanist posthumanism of thinkers such as Kurzweil and Wilson, who reify 'humanity' while simultaneously proposing a utopian vision that goes beyond it. Either we must accept the existence of a posthuman future is made possible 
by the extinction of the human species or, we must replace the reified conception of 'being human' on which such technocratic posthuman utopianism depends with a more capacious and radical transvaluation of humanity as such, which amounts ultimately to the same thing. In both Particules and these posthumanist visions of emancipation, capitalism is understood as co-extensive with the human species, so that that the selfdestructive conception of human emancipation they advance appears not as a contingent symptom of the system it seeks to exceed but as an essential and inevitable truth. Echoing Jameson's now famous apothegm on the end of capitalism and the end of the world, Wilson and Kurzweil's solution to misery under capitalism proposes in disavowed form that the end of human suffering necessarily entails the end of the human both biologically and conceptually. By contrast, Houellebecq's Particules is both explicit and sanguine about this possibility.

Perhaps then, if Particules does not provide more than a vision of our own complicity in our materialist misery and the deflation of utopian desire, we can read it as a satire of human barbarism and hubris of techno-scientific optimism. Perhaps Houellebecq parrots and stages the language and cultural forms of society's vulgar Darwinian imaginary to mock that language and those forms as well as its own complicity in them. Yet this kind of resistance, Crowley points out, is bathetic, 'humiliated, feeble, derisory', a symptom of a world addressing itself in a language that cannot even muster the 'energy to signal itself as parodic'. The temporally and materially dislodged narrative perspective of the clone in this work, then, does not offer critical, parodic, or philosophical distance from the tawdry materialism of late capitalist human society, but merely deepens the suspicion that either this distance is founded on an illusion or that the very possibility of such a distance would cost us our extinction.

Possibilité offers a more nuanced but potentially just as deflationary perspective on the emancipatory possibilities of Darwinian and neoliberal materialism. In contrast with Particules, the narrative perspective of neohuman futurity on late capitalist savagery is not provided by an exogenous narrative frame. Instead, the autobiographical narrative of Daniel1 is penetrated by those of Daniel24 and Daniel25, which are themselves comprised of exegetical commentary on the life story of their predecessor. This formal entanglement indicates a more complex understanding of the relation between the ages of materialism and post-materialist positivity. Unlike the posthuman world, neohumanity in Possibilité is not figured as a pure negation of its antecedent historical stage. Rather, traces of the old persist in the new, undermining by definition the post-historical and post-materialist age of neohumanity.

Each neohuman lives in an individual architecturally sealed enclave, surrounded by a world overcome by environmental collapse. These cell-like structures, architectural projections of neohuman autonomy, protect the neohuman from both the harsh exterior climate as well as the roving tribes of non-cloned, savage humans that still live scattered amongst the ruins of twenty-first-century civilisation. Contact with other members of the neohuman population is conducted via the exchange of digital code; otherwise their days are constituted by peaceful contemplation and their exegetical work on the life stories of previous generations - the intention of which is to extend individual human consciousness, or soul, indefinitely until the advent of post-physical noetic singularity. Such an existence is a self-deluding one; the neohuman is neither physically autarchic nor reproductively autopoietic. Reproduction is no longer 
connected to human sexual desire or relation, but has become an industrial relation, conducted between the clone and a centralised cloning centre, revealing the neohuman's immortality to be contingent. Neohumans do not ingest food, but still relies on the atmosphere for nutritive sustenance. They are not, therefore, as Daniel24 puts it, ' $[r]$ efermant la parenthèse du devenir' ['closing brackets on becoming'], but have merely repressed the fact of their becoming in a form that is nominally different to that of 'natural selection' and neoliberal social reproduction. The neohuman desire for noetic unity is similarly problematic. What are the individual neohuman cells if not spatial, temporal projections and intensifications of the atomised individualism of twenty-firstcentury life, from which they seek to escape? The novel concludes with Daniel25 departing his self-imposed evolutionary and social isolation, driven by a desire to rejoin the world of mortals. His isolation, he says, the condition of his biological transcendence, has become intolerable. He desires nothing other than the intense, masochistic pleasure of being human, which he recognises through his reading of Daniel1's life story. The interpenetration of human and neohuman existence, enacted by the novel's formal rhetoric, prefigures the manner in which traces of the old irrational materialism continue to haunt, to shape, and ultimately to destroy human self-transcendence.

This is the death-blow for the notion of a final, positive, or posthuman utopian stage made possible by evolutionary genomic technology. It is 'becoming' in its evolutionary and genomic forms, and its intensification under late capitalism, which makes immortality both desirable and materially possible. But it is the indeterminate historicity of evolutionary change, its failure to eliminate contingency, that undermines humanity's indefinite existence as well as the notion of its perfection. This is a kind of return of what is repressed by both neoliberal or late capitalism in its fusion with Neo-Darwinian and genomic science; if, ironically, our current evolutionary biopolitical conjuncture is defined by its ignorance of its own history, in this novel it is the impossible desire for evolution to transcend itself, for a repetition of the same to provide a state of exception, that undoes the very notion of transcendence from within.

Does Houellebecq in these two novels offer us anything more than a complex but ultimately pathetic reflection on the twenty-first-century biopolitical hegemony of neoliberal capitalism and the emancipatory possibilities of genomics? Like Zola's Naturalism, Houellebecq's Neo-Naturalism succeeds in bearing witness to atavistic barbarism, staging and (re-)enacting the manner in which human cruelty is determined and intensified by the popularity and eventual universality of certain reductive, essentialist conceptions of human nature in evolutionary discourse. Particules offers a savage indictment of contemporary society, as well as a critique of the utopian perspective from which this indictment is articulated-a repudiation of its very possibility. Possibilité tells a similar story, emphasising the emptiness and violence of twenty-first-century life, while at the same time suggesting that evolutionary transcendence is not only impossible, but would nevertheless be undesirable in its synthetic form, just as our own late capitalist atomisation is intolerable today. If these novels attack the essentialism and evolutionary determinism of posthumanist and transhumanist visions of the future, they also seek to repudiate the optimism that defines both these and more critically sophisticated and anti-essentialist images of posthuman emancipation. For Donna Harraway, in her 'Cyborg Manifesto', the advent of new communications and biological technologies at the close of the twentieth-century promised a new, malleable architecture of social relations with which to re-form and challenge the biological and patriarchal myths of 'organic 
wholeness' as well as means for the production of a new revolutionary subject (Harraway 1991). Houellebecq's post-gender, post-reproductive neohumans, however, merely reproduce and intensify the conditions of isolation and alienation that define late capitalist materialism, while refounding a new myth of transcendent wholeness in the form of technological singularity. Harraway's essay is cognisant of the contradictions arising from a response to domination that arises out of those same conditions: 'cyborgs [...] are the illegitimate offspring of militarism and patriarchal capitalism' $(1991,150)$. But where Harraway hopes for cyborgs that are disloyal to their origins, Houellebecq's neohumans seem more faithful than ever before to the individualism, anthropocentrism, and the buried faith in transcendence that forms the substrate of late capitalist as well as some socialist ideologies. Above all, however, the impression one gets from Houellebecq's clones is that posthumanity is fundamentally and intolerably boring, a more fully realised iteration of the anhedonia that Houllebecq's work both channels and denounces.

Houellebecq's failed clones, then, are not solutions to the desperation caused by the twentyfirst century's epistemological and material self-imprisonment, but totems of an anti-solution. They are in their irreducible ambivalence an affirmatively aporetic response to a crisis that seeks at all costs, through biological reduction and historical determinism, through an iron grip on the horizons of our political imagination, to eliminate uncertainty in all its forms. Pitiless negativity should be seen as a positive achievement of Houellebecq's literary work: its refusal, however pathetic, of both the deterministic utopianism of the Comtean posthumanism, genomics, and Neo-Darwinian thought as well as of the nihilism to which it offers a solution, which is similarly deterministic in its insistence on humanity's inalterable savagery. The end of humanity, whether through self-transcendence or self-destruction, is not pre-determinable. Aporia affirms what lies beyond the realism of capitalism and 'the survival of the fittest'futurity.

\section{Disclosure statement}

No potential conflict of interest was reported by the author.

\section{ORCID}

Niall Sreenan (D) http://orcid.org/0000-0002-5057-3259

\section{References}

Baguley, D. 2011. "Zola and Darwin: A Reassessment." In The Evolution of Literature: Legacies of Darwin in European Cultures, edited by N. Saul and S. James, 201-212. Amsterdam: Rodopi.

Baguley, D. 2014. "Darwin, Zola and Dr Prosper Lucas's 'Treatise on Natural Heredity'." In The Literary and Cultural Reception of Charles Darwin in Europe, edited by T. Glick and E. Shaffer, 416-431. Vol. 3. London: Continuum.

Best, V., and M. Crowley. 2007. The New Pornographies: Explicit Sex in Recent French Fiction and Film. Manchester: Manchester University Press.

Bostrom, N. 2004. "The Future of Human Evolution." In Death and Anti-Death, Volume 2: Two Hundred Years After Kant, Fifty Years After Turing, edited by C. Tandy, 339-371. Palo Alto, CA: Ria University Press.

Bowler, P. J. 1989. Evolution: The History of an Idea. Berkeley: University of California Press. 
Brown, W. 2015. Undoing the Demos: Neoliberalism's Stealth Revolution. 1st ed. New York: Zone Books.

Crowley, M. 2012. "Low Resistance." In On Bathos: Literature, Art, Music, edited by S. Crangle and P. Nicholls, 148-165. London: Bloomsbury.

Darwin, C. 1859. On the Origin of Species by Means of Natural Selection, or the Preservation of Favoured Races in the Struggle for Life. London: John Murray.

Dawkins, R. 1989. The Selfish Gene. Oxford: Oxford University Press.

Dennett, D. C. 1996. Darwin's Dangerous Idea: Evolution and the Meanings of Life. London: Penguin Books.

Fisher, M. 2009. Capitalist Realism: Is There No Alternative? London: Zero Books.

Foucault, M., and M. Senellart. 2008. The Birth of Biopolitics: Lectures at the Collège de France, 197879. Basingstoke, NY: Palgrave Macmillan.

Harraway, D., ed. 1991. "A Cyborg Manifesto: Science, Technology, and Socialist-Feminism in the Late Twentieth Century." In Simians, Cyborgs and Women: The Reinvention of Nature, 149-181. New York: Routledge.

Harvey, D. 2005. A Brief History of Neoliberalism. Oxford: Oxford University Press.

Hawkins, M. 1997. Social Darwinism in European and American Thought, 1860-1945: Nature as Model and Nature as Threat. Cambridge: Cambridge University Press.

Houellebecq, M. 1998. Les Particules Élémentaires: Roman. Paris: Flammarion.

Houellebecq, M. 2001. Atomised. Translated by Frank Wynne. London: Vintage.

Houellebecq, M. 2005a. La possibilité d'une île. Paris: Fayard.

Houellebecq, M. 2005b. The Possibility of an Island. Translated by Gavin Bowd. New York: Vintage. Jameson, F. 1991. Postmodernism, Or, The Cultural Logic of Late Capitalism. London: Verso.

Jameson, F. 2003. "Future City." New Left Review II (21): 65-79.

Kurzweil, R. 2006. The Singularity Is Near. London: Gerald Duckworth \& Co.

Lafargue, P. 1890. "Darwinism on the French Stage." Time, February 1890.

Lordon, F. 2001. "The Logic and Limits of Désinflation Compétitive." In Social Democracy in Neoliberal Times: The Left and Economic Policy since 1980, edited by A. Glyn, 110-137. Oxford: Oxford University Press.

Marx, K. 1965. Marx Engels Selected Correspondence, edited by S. W. Ryazanskaya. Moscow: Progress Publishers.

McCann, J. 2010. Michel Houellebecq: Author of Our Times. Oxford: Peter Lang.

Midgley, M. 2000. "Why Memes?" In Alas Poor Darwin: Arguments against Evolutionary Psychology, edited by H. Rose and S. Rose, 67-84. London: Jonathan Cape.

Moore, J. W. 2015. Capitalism in the Web of Life: Ecology and the Accumulation of Capital. New York: Verso.

Morrey, D. 2013. Michel Houellebecq: Humanity and Its Aftermath. Liverpool: Liverpool University Press.

Rabosseau, S. 2010. "Michel Houellebecq, un romancier 'néo-naturaliste'." In Le monde de Houellebecq, edited by G. Bowd, 105-113. Glasgow: University of Glasgow.

Rose, H., and S. Rose. 2012. Genes, Cells, and Brains: The Promethean Promises of the New Biology. London: Verso.

Shostak, S. 1999. Evolution of Sameness and Difference. Boca Raton, FL: CRC Press.

Sreenan, N. 2014. "Zola's Critical Naturalism(s): Germinal, Darwin, and Uexküll." In Rethinking the Real: Fiction Art and Theatre in the time of Émile Zola, edited by L. Z. Colloquium, V. Minogue, and P. Pollard, 43-54. London: Émile Zola Society.

Sweeney, C. 2013. Michel Houellebecq and the Literature of Despair. London: Bloomsbury.

Wilson, E. O. 1998. Consilience: The Unity of Knowledge. New York: Knopf.

Woollenn, G. 2013. "Plutôt darwinien bas de gamme?." In Rencontres, Série Littérature des XXe et XXle siècles, 68. 8, L'unité de l'œuvre de Michel Houellebecq, edited by S. van Wesemael and B. Viard, 179-190. Paris: Classiques Garnier.

Zola, É. 1978. Germinal (1885). Paris: Gallimard. 